\title{
Adoption of the International Public Sector Accounting Standards in emerging economies and low-income countries: a structured literature review
}

\author{
Tobias Polzer \\ WU Vienna University of Economics and Business, Vienna, Austria \\ Pawan Adhikari \\ Essex Business School, University of Essex, Colchester, UK \\ Cong Phuong Nguyen \\ University of Economics, The University of Danang, Danang, Vietnam, and \\ Levi Gårseth-Nesbakk \\ Business School, Nord University, Bodø, Norway and \\ NTNU Business School, NTNU Norwegian University of Science and Technology, \\ Trondheim, Norway
}

\begin{abstract}
Purpose - The aim of the study is to review the extant literature on International Public Sector Accounting Standards (IPSAS) adoption in emerging economies (EEs) and low-income countries (LICs) ("what do we know?"), and to propose an agenda for future research ("what do we need to know?").

Design/methodology/approach - An analytical framework that builds on diffusion theory is developed. The authors follow the "PRISMA Flow Diagram" to reduce a total of 427 articles from four databases to a final sample of 41 articles. These studies are examined, aided by the analytical framework.

Findings - The authors find that IPSASs are a relevant issue for EEs/LICs. Overall, existing research is often explorative. The authors discover that the majority of articles rely on secondary data collection. While twothirds of the studies perform a content analysis of pre-existing material, about one-fifth of the articles each collect primary data through means of interviews and questionnaires. The findings offer a holistic understanding of where and at what stages IPSAS reforms stand in EEs/LICs, and what factors influence the progression of reforms to the next stage of diffusion.

Originality/value - The authors outline a number of avenues for further research after discussing the dominating trends and structuring the literature based on our analytical framework. These stem from looking at the blank spots and an identified need to contextualise IPSASs adoption in EEs/LICs.
\end{abstract}

Keywords Public sector accounting, International Public Sector Accounting Standards (IPSAS), Emerging economies, Low-income countries, Structured literature review

Paper type Research paper

(C) Tobias Polzer, Pawan Adhikari, Cong Phuong Nguyen and Levi Gårseth-Nesbakk. Published by Emerald Publishing Limited. This article is published under the Creative Commons Attribution (CC BY 4. 0) licence. Anyone may reproduce, distribute, translate and create derivative works of this article (for both commercial and non-commercial purposes), subject to full attribution to the original publication and authors. The full terms of this licence may be seen at http://creativecommons.org/licences/by/4.0/legalcode

The authors thank the two anonymous reviewers for their thoughtful comments on the manuscript. The authors are indebted to the participants of the AAEE 2018 and EGPA 2019 conferences for the valuable feedback received. The authors would like to thank Editor-in-Chief Giuseppe Grossi for his guidance through the review process. This work was supported by the British Academy/Newton Mobility Grant (Grant Number NG160355). The usual disclaimer applies.

Adoption of the IPSAS in EEs

Received 27 January 2021 Revised 20 May 2021 5 August 2021

Accepted 11 August 2021

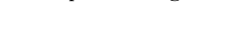




\section{Introduction}

This research stems from our interest in understanding "what is known about the adoption of International Public Sector Accounting Standards (IPSAS) in emerging economies (EEs) and low-income countries (LICs)" [1] and "what needs to be known", and is based on a systematic review of the literature. The harmonisation of financial reporting in the public sector has been one of the major components of recent public sector accounting (PSA) reform initiatives (Manes Rossi et al., 2016). In this context, the IPSASs have become an international benchmark for evaluating PSA reforms (Ben Amor and Damak Ayadi, 2019; Polzer et al., 2021a).

While a number of literature reviews have been conducted on IPSASs adoption (Polzer et al., 2020; Schmidthuber et al., 2020), the focus has been on western countries, which represent not more than $10 \%$ of the global population. A recent systematic review of IPSASs (Schmidthuber et al., 2020) refers to the context of EEs and LICs only sporadically. However, a more dedicated focus on the adoption contexts is regarded as highly relevant when analysing IPSASs in EEs/LICs. This is because although some scholars hold the view that EEs and LICs could potentially "benefit more from accounting reforms [such as the adoption of IPSASs] than developed countries" (Schmidthuber et al., 2020, p. 13; Chan, 2006), such voices are, however, in the minority. The dominant view asserts the fact that accounting solutions that have been developed in western countries do not always suit the context of EEs and LICs (Hopper et al., 2017; Soobaroyen et al., 2017).

Given this, the present study aims to add to a growing body of literature on PSA harmonisation in line with IPSASs, bringing out the case of EEs/LICs. This issue has also received increasing interest from practitioners (e.g. ACCA, 2017; PwC, 2013). Our review is based on the methods that have been used by various other scholars in their reviews of PSA in EEs/LICs (e.g. Nolte et al., 2021; van Helden and Uddin, 2016). The research questions are as follows:

$R Q 1$. What dominating trends can be identified in the literature on IPSASs adoption in EEs and LICs over time?

RQ2. What are the potential avenues for further research on IPSASs in EEs and LICs?

The remainder of the paper is structured as follows. In the next section (Section 2), we present a conceptual orientation, where our research phenomenon is briefly outlined, and an analytical model based on diffusion theory is developed. We then provide an overview of the research methodology (Section 3), followed by a categorisation of reviewed publications (Section 4). Finally, we discuss findings and outline avenues for further research (Section 5).

\section{Conceptual orientation}

2.1 Research phenomenon - IPSASs and their adoption in EEs and LICs

IPSASs have emerged standard by standard since the establishment of the Public Sector Committee of the International Federation of Accountants (IFAC) in 1986, which was later transformed into the IPSAS Board (IPSASB) (Christiaens et al., 2015; Polzer et al., 2021d). The IPSASs follow the (accrual-based) International Accounting Standards/International Financial Reporting Standards (IASs/IFRSs) as much as appropriate, with some differences (additional commentaries, different terminologies and definitions). In addition, IPSASs have attempted to cater to the particularities of the public sector, such as the disclosure of information about the general government sector or revenues from nonexchange transactions (taxes and transfers). The outreach of the IPSASB to practitioners and academics has increased over the past years (Jensen, 2020). 
Although the priority of the IPSASB has been to promote the accrual-based IPSASs, EEs and LICs are encouraged, particularly by international organisations, to adopt the Cash Basis IPSAS as a necessary first step for a longer-term transition towards accrual-based IPSASs (Adhikari et al., 2015). In a comparative study of IPSASs adoption in South Asia, Adhikari and Mellemvik (2010) illustrate how the World Bank, in collaboration with professional accounting institutions, was involved in creating a myth in the region; an underlying assertion was that a transition towards accrual accounting would not yield any results without first complying with the Cash Basis IPSAS.

Claimed benefits for governments of adopting the IPSASs include, among others, enhanced accountability and transparency, improved decision-making and increased efficiency (Polzer et al., 2021d). Such benefits abound in the reports and documents issued by international standard setters such as the International Federation of Accountants (see e.g. IFAC, 2011), international organisations (e.g. World Bank, 2010) and professional accounting associations and accounting firms (e.g. ACCA, 2017; PwC, 2013). For instance, the World Bank (2010, p. 8) argues that the "[a]pplication of IPSAS will support developments in public sector reporting directed at improved decision making, financial management and accountability and will be an integral element of reforms directed at promoting social and economic development”. Also, more favourable conditions in capital markets are expected for adopters due to a better understandability of financial reports by rating agencies (IPSASB, 2010). Other declared benefits concern governmental professionalisation and an access to younger talent, government stability and international comparability (ACCA, 2017).

However, despite such claims, the literature suggests that convergence and harmonisation of accounting systems (such as through the adoption of IPSASs) may face challenges, with regard, for example, to diverging national traditions, to implementation costs or to preserving sovereignty (Manes Rossi et al., 2016; Polzer et al., 2021b). In some countries, the reluctance towards the implementation of IPSASs is quite intense (e.g. Oulasvirta, 2014). EEs and LICs might have less discretion, as the drive "to adopt the IPSASs mainly comes from external groups such as donors, consultants and the accountancy profession. These external groups have their own interest, which is not always the interest of the country concerned" (Hepworth, 2017, p. 147). As a result, attempts made by many EEs and LICs to embrace IPSASs have proved to be problematic at the implementation stage (Adhikari et al., 2019; Polzer et al., 2020). Hepworth (2017, p. 141) notes "that the implementation of the accrual-based IPSASs in European-influenced developing and transition economy countries is not an appropriate reform unless preceded or accompanied by other, essentially managerial, reforms".

Other studies have emphasised the particularities of EEs and LICs in the area of PSA and governance, examples, among others, being limited planning; poorly grounded reform recipes, mainly the pursuit of once-size-fits-all approaches; inadequate IT facilities and human resources; and the intervention of consultants and professional accountants (see, e.g. Adhikari and Jayasinghe, 2017). For instance, success of IPSASs in the Asia-Pacific region is limited and rarely is any evidence available delineating the planned implementation of the standards (Harun et al., 2019). Adhikari and Mellemvik (2011), focusing on Nepal, state that the country declared the adoption of IPSASs at a time when it was struggling even to operate a simple form of cash accounting, let alone accrual accounting. This decision was reversed later by prioritising the adoption of the Cash Basis IPSAS, a decision which took a decade to put into practice due to resource constraints (Adhikari et al., 2015).

In a similar vein, several scholars have demonstrated the challenges that Latin American countries have faced in complying with IPSASs, and have made a claim that hardly any countries in the continent have fully implemented IPSASs in practice as intended, despite their enduring commitments to IPSASs (e.g. Cavanagh and Fernández Benito, 2016). Gómez-Villegas 
et al. (2020, p. 495) state that "there is more rhetoric than practice" in Latin America, even though most of the countries had already started to embark on implementation years ago.

In Africa, IPSAS reforms have drawn more critics for further weakening the existing accountability mechanisms, thereby impinging on governance problems, patronage politics and endemic corruption (Hopper et al., 2017; Lassou, 2017). For example, in their study of Nigeria, Bakre et al. (2017) demonstrate how the adoption of IPSAS 17 was manipulated to continue using the historical costs in property valuation, which largely benefitted politicians, public officers and their family members. In their study of Tanzania, Goddard et al. (2016) illustrate how resource constraints and donor pressures have led to the manipulation of the compliance of financial statements prepared by local governments.

More recently, Jayasinghe et al. (2020) point out that there is the danger that positive aspects of local accounting practices in EEs and LICs are deliberately ignored by the epistemic community when disseminating IPSASs. However, in many EEs and LICs, local accounting and reporting practices already far exceed the requirements laid down in that standard. (Jayasinghe et al., 2020). It is important to note in this context that PSA reforms are not neutral, but always have a political and ideological component (Bakre et al., 2021; see also Adam, 2018; Cenar, 2012; Mattei et al., 2020). More specifically, in terms of the IPSASs, a number of critical opinions have been raised - for example, that they are being issued by an authority that is not democratically legitimated (the IPSASB, Brusca et al., 2013). There are also critical remarks that the IPSASs represent the Anglo-Saxon method of PSA (Oulasvirta, 2014). They are claimed to be irrelevant in the contexts where the budget has continued to dominate (Adhikari and Gårseth-Nesbakk, 2016). In the following, we develop an analytical framework in order to trace to what extent the argued benefits and critical issues manifest in EEs and LICs.

\subsection{Analytical framework - diffusion theory}

Diffusion theory concerns providing an understanding of how innovations in the forms of ideas, practices or standards are disseminated in a specific context (Jackson and Lapsley, 2003; Rogers, 2003). The application of the theory has steadily increased in accounting research, not least PSA (Dissanayake et al., 2020; Ezzamel et al., 2014; Lapsley and Wright, 2004; Thoradeniya et al., 2020). In the context of EEs/LICs, researchers have drawn on the theory to examine, for example, the unintended consequences of PSA reforms in countries such as Nepal (Adhikari et al., 2015), Sri Lanka (Dissanayake et al., 2020) and Egypt (Adhikari et al., 2019).

With the help of diffusion theory, researchers have demonstrated the extent to which PSA reforms vary in different contexts due to multiple external and internal factors, and formal and informal channels of communication (Adhikari et al., 2015; Lapsley and Wright, 2004). In this regard, the essence of applying diffusion theory concerns its ability to bring out distinct trajectories in the reform process. Such holistic insights are paramount to shed light on the causes of unintended consequences in PSA in general and IPSASs adoption in particular (Ezzamel et al., 2014; Polzer et al., 2020).

For the purpose of this study, we developed an analytical framework (Table 1) to assess the literature, focusing on two key elements. First, we categorise the identified articles alongside the five stages involved in the diffusion of innovations, as described by Rogers (2003) - this is the upper half of the table. When we refer to IPSASs adoption, we use this term as an umbrella term for (potentially) all five stages. Second, as the context for IPSASs adoption differs in EEs and LICs (Hopper et al., 2017; Soobaroyen et al., 2017), our framework allows us to take the contextual conditions for each stage explicitly into consideration - this is the lower half of the framework.

The first stage of Rogers' (2003) model (seeking knowledge about reform innovations) highlights information-seeking processes. This stage is strongly guided and influenced by already available knowledge. In the context of the public sectors in EEs and LICs, pre-existing knowledge about accrual accounting might be limited (Adhikari et al., 2015) or accounting systems might be generally less developed (Chan, 2006). 


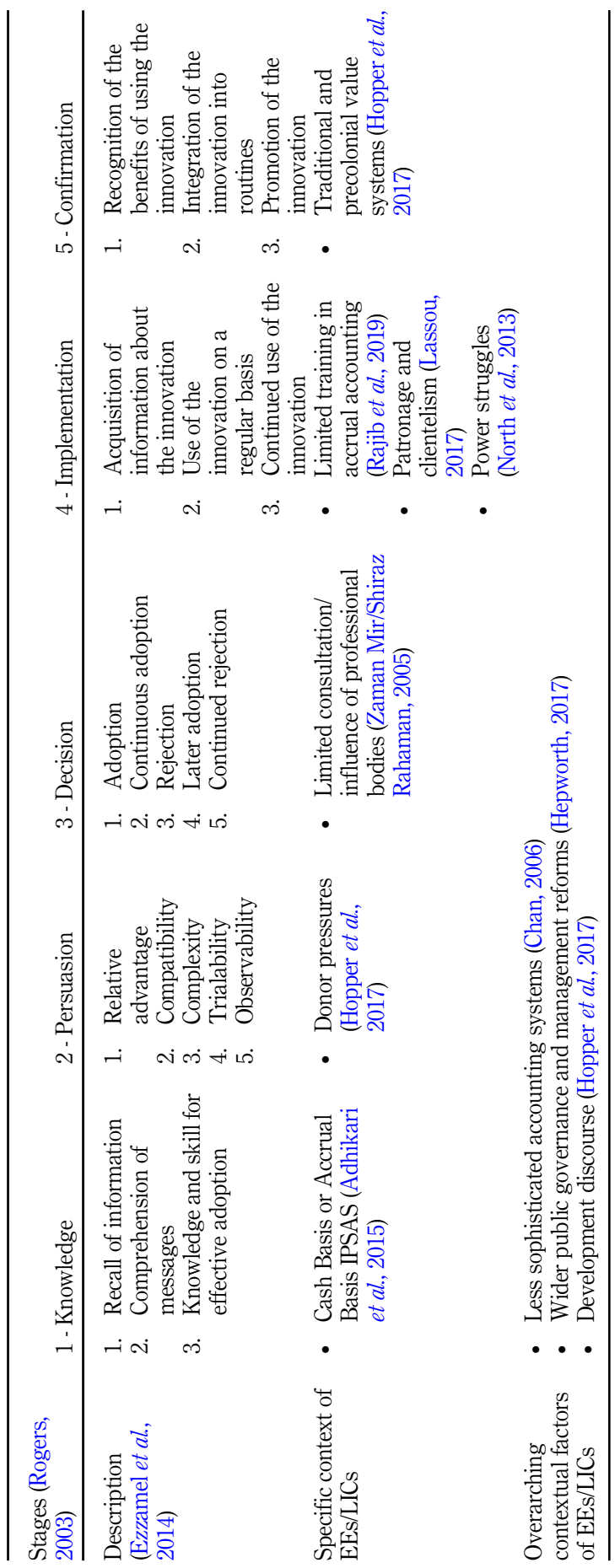


Persuasion is the second stage in Rogers' (2003) model. Establishing consensus about the need and rationale of IPSASs adoption is a complex social process where multiple actors are involved (on the administrative and political side, professional accounting bodies and international (donor) and non-profit organisations). During this stage, the innovation is often contested. A range of factors increase the likelihood of an innovation becoming accepted: its complexity; piloting of the innovation; the fit with the adopter's existing values; the expected benefits from the innovation; and the possibility of actually observing the results of the innovation. In the EE/LIC context, donor pressures might be the dominant driver of persuasion (Hopper et al., 2017), limiting the influence of actors within a country. Indeed, PSA reforms introduced in EEs/LICs have been mostly a supplier-led initiative resulting from the loan conditionality and development discourses of international organisations such as the World Bank and the IMF, which is evident in extant work (Adhikari et al., 2019). International organisations have demonstrated pro-innovation biases in EEs/LICs, designating IPSASs as the best accounting practices which could lead to improved governance and accountability (Adhikari and Mellemvik, 2010; Jayasinghe et al., 2020).

The decision (stage 3) involves the formal approval or rejection of a law or framework document to implement IPSASs. In practice, a decision can come in different forms - for example, a decision for sequencing (Bietenhader and Bergmann, 2010), or a partial approval. The decision has to be made by a legitimate actor, which could be, for example, Parliament, the cabinet, a responsible minister or the accounting standards board. In the context of EEs and LICs, reform decisions are often taken in a top-down manner, i.e. without consulting local implementing organisations or those who are actually involved in implementing reforms (Zaman Mir and Shiraz Rahaman, 2005).

Once the decision to adopt IPSASs has been made, the implementing organisations (in particular, government ministries and agencies) move to stage 4 -implementation (Rogers, 2003). However, implementation is not a simple application of the legal or guidance material resulting from the decision, but also involves its active interpretation in the specific policy context. The implementation requires knowledge transfer and boundary-spanning activities (Jackson and Lapsley, 2003) to ensure a meaningful application. However, at the same time, some actors may seek to modify or reinvent the innovation, partly driven by the need to cater for the specific local and organisational circumstances (Baskerville and Grossi, 2019; Mouritsen, 2005). From the extant literature on implementing reforms in EEs and LICs, it is known that power struggles over resources by different individuals and societal groups (North et al., 2013), a lack of resources (Gómez-Villegas et al., 2020) and extended training needs of civil servants (Rajib et al., 2019) are the factors that might pose challenges to the implementation of reforms. Adhikari et al. (2019) state that implementation has been reckoned to be the most complex and problematic stage within the diffusion trajectory, as well as the stage in which the factors and causes of unintended consequences become much clearer.

The final stage 5 - confirmation - is reached when the IPSASs have become an institutionalised and legitimate practice beyond the formal implementation and gain legitimacy (Rogers, 2003). Stakeholders start to recognise the benefits and the innovation spreads throughout the PSA system. The question of how enduring change can be achieved has also been intensely discussed in the PSA literature (e.g. Liguori and Steccolini, 2012). For EEs and LICs, changing traditional and precolonial values (Hopper et al., 2017) might be an additional challenge. Also, very often the adoption of an innovation seldom happens in isolation, but is connected to wider reforms (Hepworth, 2017). With this, judging the outcomes of IPSASs adoption in solitude is challenging.

While the significance of the five stages of the diffusion model and their analytical value were confirmed in prior work, also in the area of PSA (Ezzamel et al., 2014), we assume that the stages are not clear-cut in practice, but rather serve to structure and rationalise developments ex post. Furthermore, in the context of EEs/LICs, studies discussing (1) the stages of diffusion 
that PSA reforms pass through and (2) the contextual conditions in each stage (which might Adoption of the result in unintended consequences) are scarce, with a few exceptions (see, e.g. Adhikari et al., IPSAS in EEs 2015). We intend to address this theoretical gap in this study.

\section{Research approach}

Systematic literature reviews have become increasingly popular in PSA (De Waele et al., 2021; Schmidthuber et al., 2020) and also in the EE/LIC context (e.g. Nolte et al., 2021; Van Helden et al., 2021; van Helden and Uddin, 2016). The purposes of such reviews are to identify the areas of a research field where substantial progress was made and to outline future directions of research (Bracci et al., 2019; Massaro et al., 2016). In our study, we follow the "PRISMA Flow Diagram" (Moher et al., 2009) to ensure reproducibility (Figure 1). This flow chart has gained recent popularity for review studies in public sector research (e.g. de Vries et al., 2016).

\subsection{Identification of studies}

The searches were carried out in autumn 2020. As shown in Table 2, 16 queries in four literature databases that are commonly used in the social sciences yielded 427 results for a full-text search (the table reports databases and search terms). We did not limit our search to any particular years, so we cover articles from 2003 (being the year when the first relevant article on IPSASs appeared) to 2020. We also did not exclude any subject categories, as we wanted to obtain results from potentially the accounting, development and public administration research areas. However, we limited the results to peer-reviewed journal articles (i.e. excluding book chapters and conference papers) in English, where this was allowed by a database. Such an exclusion strategy is recommended in order to obtain

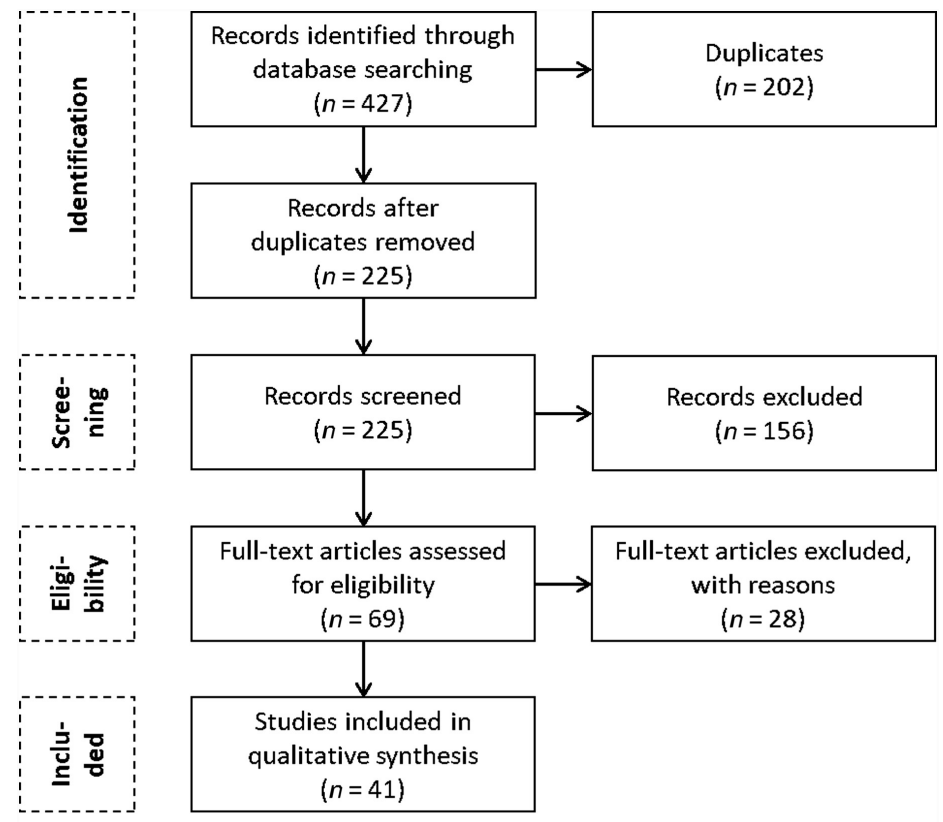

Source(s): Based on Moher et al. (2009)

Figure 1.

Flow diagram for systematic literature review 
Table 2.

ipsas AND "emerging econ*”

"international public sector accounting standards" AND

"emerging econ*"

ipsas AND "developing count*"

"international public sector accounting standards" AND

"developing count*"

ipsas AND "emerging econ*"

"international public sector accounting standards" AND

"emerging econ*"

ipsas AND "developing count*”

"international public sector accounting standards" AND

"developing count*"

[STRICT] ipsas AND “emerging econ*”

[STRICT] "international public sector accounting standards"

AND "emerging econ*"

[STRICT] ipsas AND “developing count*”

[STRICT] "international public sector accounting standards"

AND "developing count*"

ipsas AND "emerging econ*"

"international public sector accounting standards" AND

"emerging econ*"

ipsas AND "developing count*”

Ebsco Business Source

Premier

90

Web of Science 6

"International Public Sector Accounting Standards" AND

"developing count*"

Total
Web of Science 4

8
5

Collection 39

73

78

Scopus $\quad 5$
Proquest Business Premium 35

validated knowledge on an issue (Podsakoff et al., 2005; Polzer et al., 2021c). After we removed duplicates in the next step, the number of records decreased to 225.

\subsection{Screening}

Next, the relevance of search hits was assessed (Manes Rossi et al., 2020). We performed an initial screening of title, abstract and keywords of each article in order to establish if each one actually focused on IPSASs as a (potential) main topic (Moher et al., 2009). This further reduced the sample to 69 . Following such an approach, articles that were not focusing on IPSASs at all (but instead on, for example, street trading in South Africa; Bénit-Gbaffou, 2018) or mentioned IPSASs only in a footnote (e.g. Tooley et al., 2010) were excluded.

\subsection{Eligibility and included studies}

During the following step - the eligibility check - we reduced our data set to 41 articles after analysing if the IPSASs were actually a central topic of the article. This led, for example, to the exclusion of an initially promising paper on the quality of public sector financial statements (Ratmono and Sutrisno, 2019), which was later not deemed eligible because it covered IPSASs only very marginally. After the eligibility check, 41 papers were included in our analysis.

\subsection{Analysis}

We structure our findings alongside the following dimensions, as suggested by Massaro et al. (2016): (a) year of publication, (b) journal ranking, (c) number of citations per year, (d) country and tier of governments, (e) research strategies and methods, (f) conceptual orientation of the 
studies, (g) keywords and thematic embedding and (h) categorisation of the main findings with respect to the elements of the established analytical framework (Table 1).

In terms of (b) journal ranking, we draw on a measure developed by Scimago Lab. "SCImago JCR" is a form of impact factor and shows the journal citation ranking of 2019 as per the definition developed by Scimago Lab (Scimago Research Group, 2007). In addition to traditional impact factors, this ranking takes into account the prestige of the citing journal. With respect to $(\mathrm{g})$ thematic embedding, extant research found that governments seldom introduce new reform tools (such as the IPSASs) on their own, but often on top of, or interwoven with, existing ones (Hepworth, 2015). We therefore expect that pieces covering IPSASs adoption are frequently related to studies focusing on prevalent, more general PSA topics. To make the interlinkages visible, we draw a network of co-occurrences of author keywords from the articles (Kumar et al., 2020) in an additional analysis (34 of the 41 identified articles contained keywords).

Turning to (h) categorisation of the main findings, we assigned for each of the articles five values between 0 (minimum) and 3 (maximum) with respect to its focus on knowledge, persuasion, decision, implementation and confirmation as per our analytical framework (Table 1) based on the model by Rogers (2003). For example, the article by Timoshenko and Adhikari (2010) that compared IPSASs implementation in Nepal and Russia focused on the decision (coded as 2) and implementation (also coded as 2) stages. Coding reliability was ensured by team coding: all preliminarily coded values were double-checked by two members of the research team and discussed, until consensus in the interpretation was reached among the team.

\section{Findings}

\subsection{Descriptive analysis}

4.1.1 Year of publication and outlet. An analysis of the number of articles published per year shows that research on IPSASs in EEs and LICs has gained momentum over the years (see Figure 2). With the first eight IPSASs published in 1999, IPSASs become an important PSA reform issue in EEs and LICs relatively quickly and the first paper with an IPSASs focus was published four years later (Chan, 2003). We can observe an increasing trend in publications on IPSASs over the years (see the dotted trend line - nine papers in 2020), which is also due to a Special Issue in the International Journal of Public Sector Management (Nurunnabi, 2020).

Looking at the outlets of the identified research papers and using the SCImago JCR 2019 ranking as a benchmark, we find that the article by Bakre et al. (2017) is the one that has been published in the journal with the highest JCR score (Accounting, Auditing and Accountability

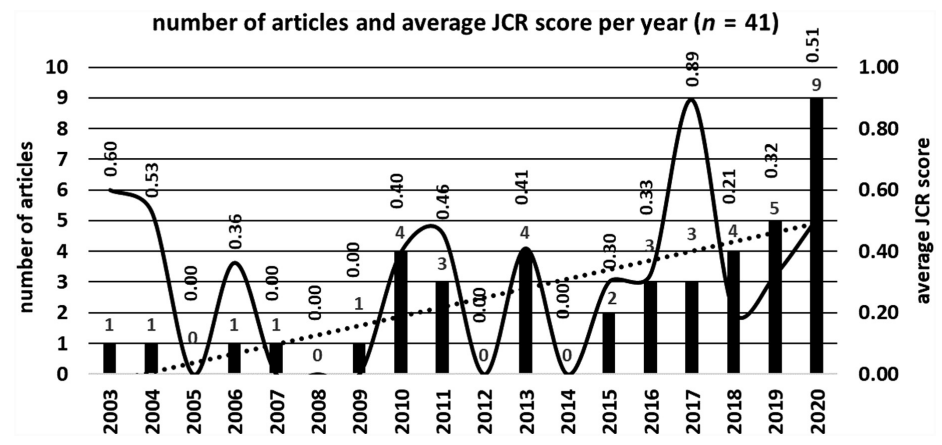

Figure 2. Articles per year, 2003-2020 
Journal: 1.459 - comparators: Accounting, Organizations and Society: 1.924; Critical Perspectives on Accounting: 1.823). The majority of the articles are published in low to medium-ranked journals (JCR values under 1). Just $7.3 \%$ of studies are from outlets with a higher score. When looking at the averages of JCR values per year (solid line in Figure 2), no clear trend emerges; for example, we cannot observe that the discourse is moving towards outlets with higher impact factors.

4.1.2 Citations per year. The papers that have the highest citations per year (a top ten ranking as per counts on the Google Scholar website divided by years) are listed in Table 3. The papers by Chan (2003) and Torres (2004) include evidence from both western countries and EEs/LICs. This means that the issue has gained some scholarly attention over the last years. Other frequently cited papers (in absolute terms) include Saleh and Pendlebury (2006), with 59 citations, Grubišić et al. (2009), with 42 citations and Deaconu et al. (2011), with 41 citations.

4.1.3 Locus of studies. Our country analysis (Table 4) shows that the majority of studies $(39.0 \%)$ are cross-country analyses (e.g. two-country case study comparisons - Ghana and Benin: Lassou, 2017; Nepal and Russia: Timoshenko and Adhikari, 2010; Arab region: Abushamsieh et al., 2013; Central America: Araya-Leandro et al., 2016; quantitative comparisons of 87 countries: Amiri and Hamza, 2020). There are three studies (7.3\%) each from Indonesia (e.g. Fahmid et al., 2020) and Romania (e.g. Tiron Tudor, 2010), as well as two $(4.9 \%)$ each from Russia (e.g. Legenkova, 2016), Nepal (e.g. Adhikari and Jayasinghe, 2017) and Nigeria (e.g. Mustapha et al., 2019). The remaining articles (31.7\%) represent a further 13 countries. With this, there is a degree of empirical breadth of research in our sample, with accounts from all continents.

\begin{tabular}{llccc}
\hline Rank & References & $\begin{array}{c}\text { Citations per } \\
\text { year }\end{array}$ & $\begin{array}{c}\text { Absolute } \\
\text { citations }\end{array}$ & $\begin{array}{c}\text { SCImago JCR 2019 } \\
\text { score }\end{array}$ \\
\hline 1 & Chan (2003) & 26.3 & 473 & 0.600 \\
2 & Torres (2004) & 7.8 & 133 & 0.530 \\
3 & Adhikari and Mellemvik (2011) & 7.5 & 75 & 0.270 \\
4 & Adhikari and Jayasinghe (2017) & 6.8 & 27 & 0.953 \\
5 & Antipova and Bourmistrov & 6.5 & 52 & 1.078 \\
& (2013) & & & \\
6 & Bakre et al. (2017) & 6.5 & 26 & 1.459 \\
7 & Lassou (2017) & 5.8 & 23 & 0.270 \\
8 & Fahmid et al. (2020) & 5 & 5 & 0.600 \\
9 & Polzer et al. (2020) & 5 & 5 & 0.596 \\
10 & Mir and Sutiyono (2013) & 5 & 40 & 0.309 \\
\hline
\end{tabular}

Table 3.

Citations per year (as of December 2020)

\begin{tabular}{lrlr}
\hline Countries & $\%$ & Tier(s) of government & $\%$ \\
\hline Multiple & 39.0 & Central & 56.1 \\
Indonesia & 7.3 & Regional/state & 2.4 \\
Romania & 7.3 & Local & 4.9 \\
Nepal & 4.9 & Organisational & 2.4 \\
Russia & 4.9 & Multiple & 9.8 \\
Nigeria & 4.9 & Unspecified & 24.4 \\
Other single countries & 31.7 & & 100.0 \\
Total & 100.0 & Total &
\end{tabular}


Table 4 also shows which tier of government is being analysed. The majority of studies $(56.1 \%)$ focus on central government. While the state/regional level is targeted in only one single study (2.4\%: Sour, 2020), there are just two (4.9\%, e.g. Mir and Sutiyono, 2013) on the local government level. The study by Deaconu et al. (2011) focuses on the level of single public sector organisations. Finally, 9.8\% of studies research IPSASs adoption in multiple levels of government.

4.1.4 Research design. For analysing the research design, we draw on van Thiel's (2014) distinction between research strategies and methods (Figure 3). Regarding the former, we differentiate between experiment, survey, case study, desk research and other. Regarding the latter, we categorise the sampled papers alongside the categories of observation, questionnaire, interview, content analysis, secondary analysis, meta-analysis, mixed methods (only if explicitly mentioned) or other. As a study can make use of more than one strategy and method, we code the two main methods applied.

Our analysis reveals that primary data are collected in about $40 \%$ of the studies, and that about two-thirds of the articles follow the qualitative paradigm. In terms of research strategy, about half of the publications are based on desk research (e.g. Carolini, 2010; Hepworth, 2015). About a quarter follow a case study approach to explore IPSASs adoption. Moving on to the research methods, in over $50 \%$ of the studies a form of content analysis is carried out, often without collecting primary data (e.g. Amiri and Hamza, 2020; Deaconu et al., 2011). About $20 \%$ of the papers analyse primary data collected through means of questionnaires (e.g. a survey among 223 accountants in local governments - Antipova and Bourmistrov, 2013) and interviews (e.g. 80 semi-structured conversations in Jordan: Alsharari, 2020). Very few studies reanalyse existing data or use other techniques (e.g. Ben Amor and Damak Ayadi, 2019; Kartiko et al., 2018). We find no studies that use advanced methods such as experiments. This demonstrates that existing research is often explorative.

4.1.5 Conceptual background. Next, we are interested in how the studies are anchored in the literature, i.e. which theory/-ies were mobilised as an analytical framework. To shed light on this question, we coded up to three conceptual lenses per article (as more than one lens could be mobilised). The results (Figure 4) show that about one-third of the articles are not explicitly conceptually anchored. For example, the recent overview by Fahmid et al. (2020), which looks at recent developments in the adoption of IPSASs worldwide and in particular at the different governmental ties in Indonesia, draws on no particular conceptual orientation.

Another quarter draw on new institutional theory (Greenwood et al., 2017). Also, the overview by Van Helden et al. (2021) finds that this theory has dominated PSA research in
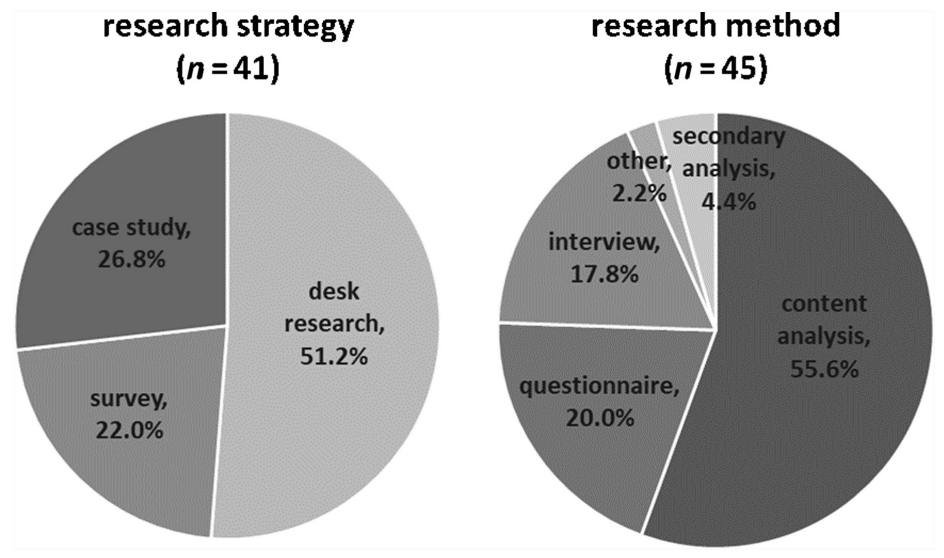

Adoption of the IPSAS in EEs 


\section{JPBAFM}

Figure 4.

Conceptual

background of studies

\section{conceptual background of studies}

$(n=47)$

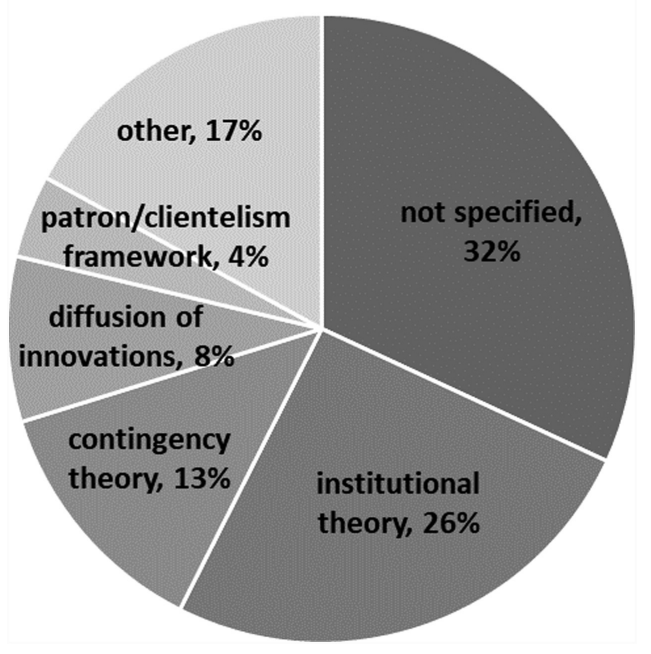

EEs and LICs in the last decade. Here, a number of studies delve into the different aspects of isomorphism, for example how international donors and organisations exert pressures to implement IPSASs. A study by Hassan (2015) is one of them, looking at the coercive pressures by international lenders on the transformation to more accrual-based accounting practices (including towards IPSASs adoption) in the Indonesian government. An empirical account from Turkey (Ada and Christiaens, 2018, p. 8) holds the view that "[t]he influence of IFAC and IPSASB are examples of normative forces being exerted for the adoption of IPSAS”. Traces of mimetic isomorphism are identified in the work by Timoshenko and Adhikari (2010, p. 474) for Russia, where "mimetic isomorphic pressures may have acted along with normative and coercive ones [... stemming] from a plethora of international agencies and departments worldwide [...], which all have been somehow embedded in the transformation process". Other studies embody the concept of decoupling and connected concepts in new institutional theory. For instance, drawing on the concept of organisational façades, Lassou's study on Ghana and Benin finds that (2017, p. 502) "[w]hile decoupling occurred in the study contexts in different ways, adopted reforms and their subsequent implementation appeared to represent façades". Yet other papers refer to institutional logics and institutional entrepreneurship (e.g. Rajib et al., 2019).

Thirteen percent of the studies focus on IPSASs adoption mobilising the lens of contingency theory, which was made available to PSA research by Lüder (1992). For example, scrutinising the case of IPSASs adoption in Nigeria, Mustapha et al. (2019) find that the quality of reporting according to the Cash Basis IPSAS is contingent on a number of organisational factors, with accounting staff competency significantly and positively influencing the perceived reporting quality. Looking at the adoption process of IPSASs in Sri Lanka through the lens of contingency theory, De Silva Lokuwaduge and De Silva (2020, p. 191) conclude that "prevailing political uncertainty in Sri Lanka has negatively impacted the implementation process".

Papers that fall under the category of other $(17 \%)$ use yet another conceptual background. We subsume all approaches under this category that appear only once in the sample. Here, 
studies such as the one by Adhikari and Jayasinghe (2017), which mobilises strong structuration theory, are noteworthy. Another example is the paper by Torres (2004) that looks at Mercosur countries (among others). Using Cooke's Index as a starting point, this research takes IPSAS 1 as a benchmark and evaluates the information content of financial statements. The study also describes "to what extent the IPSASs are able to fit into diverse public administration styles in order to improve the transparency, accountability and reliability of the financial information disclosed" (Torres, 2004, p. 447).

Finally, it needs to be noted that several articles combine some of the described theories. The paper by Polzer et al. (2020) that develops a framework that combines institutional and diffusion theory is an example. The research evaluates if the IPSAS reform walk (actual implementation) matches the reform talk (announcement). Some authors complete their analytical frameworks with yet other theories, such as contingency theory combined with institutional and economic network theories (Amiri and Hamza, 2020).

4.1.6 Thematic embedding of IPSASs. The network in Figure 5 shows how the keywords from the abstracts of the reviewed studies are linked to each other (co-occurrences; Kumar et al., 2020). Each keyword represents a node, and a link between keywords is established if they are mentioned in the same article or if the same keyword is mentioned in two different articles. The more links nodes are sharing, the closer they are positioned to one another. This approach helps to show the links between IPSASs and further instruments, ideas, actors, discourse communities and geographic areas. In order to focus on the most prominent links, we defined a threshold of two co-occurrences for ties to be included in the network.

Figure 5 shows that the IPSASs are linked to multiple nodes. The most frequent co-occurrences are, somewhat unsurprisingly, with accrual accounting and public sector (both

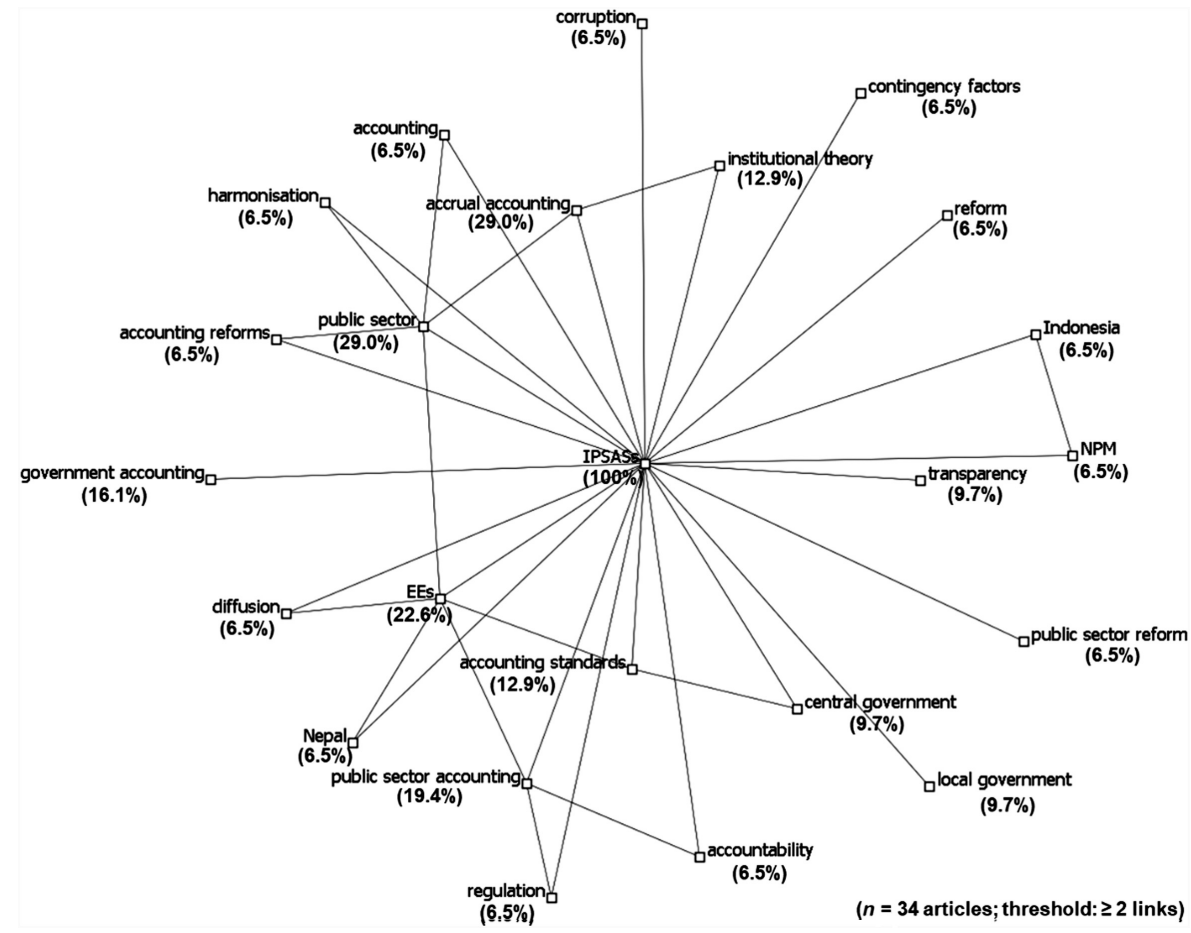

Adoption of the IPSAS in EEs - 
$29.0 \%$ ), followed by EEs (22.9\%). Grouping the links, we first identify a thematic embedding of IPSASs with the targets pursued with their implementation (accountability, transparency, harmonisation and, maybe of particular relevance to EEs and LICs, corruption). Second, we find references to general accounting issues and accounting standards (such as accounting reform, accounting standards and accrual accounting), PSA (public sector accounting and government accounting) and wider public sector reforms (public sector reform and NPM (New Public Management)). Third, country clusters appear in the network (Indonesia and Nepal). Looking closer at these clusters, the papers on Indonesia are related to ideas of NPM (e.g. Fahmid et al., 2020) and the studies on Nepal to the EEs context (e.g. Adhikari and Mellemvik, 2011). Fourth, three conceptual lenses that are mobilised in the studies come to the fore (institutional theory, diffusion and contingency factors). Finally, the keywords refer to two government tiers where the adoption of IPSASs takes place - central government and local government.

\subsection{Content analysis}

In this section we revisit the individual elements of our analytical framework, as illustrated in Table 1. We have developed Figure 6, to show the focus of studies, i.e. if a particular study addresses one of the five stages (an article could focus on more than one stage) of Rogers' (2003) diffusion model ( 0 being the minimum and 3 being the maximum with respect to its focus on knowledge,persuasion, decision, implementation and confirmation). The figure indicates that the implementation stage is the most researched one (1.63 of 3), while research addressing the persuasion stage is scarce (0.07). A score of around 0.5 is reached for the other three stages.

4.2.1 Knowledge. About one-fifth of papers (i.e. nine out of 41) address the first stage, knowledge. For example, the normative study by Hughes (2007) illustrates four steps for the adoption of IPSASs and suggests an implementation plan. There is also evidence from Bahrain (a survey among 80 civil servants; Elmezughi and Wakil, 2018) that knowledge about the innovation might be an issue. While $59 \%$ of respondents feel a lack of knowledge accrual accounting in general, $68 \%$ feel uneasy with IPSASs. Regarding valuation according to IPSASs, $63 \%$ of respondents expect difficulties in the valuation of inventory and $69 \%$ in the valuation of fixed assets such as infrastructure and heritage assets. Applying a diffusion theory lens (Rogers, 2003) and looking at various factors that influence the readiness of the public sector to adopt IPSASs in Qatar, Abdulkarim et al. (2020, p. 490) conclude that "despite the availability of highly skilled professionals among public sector staff in Qatar, it is still

Figure 6. Revisited analytical framework focus of studies/importance of

stages $(n=41)$

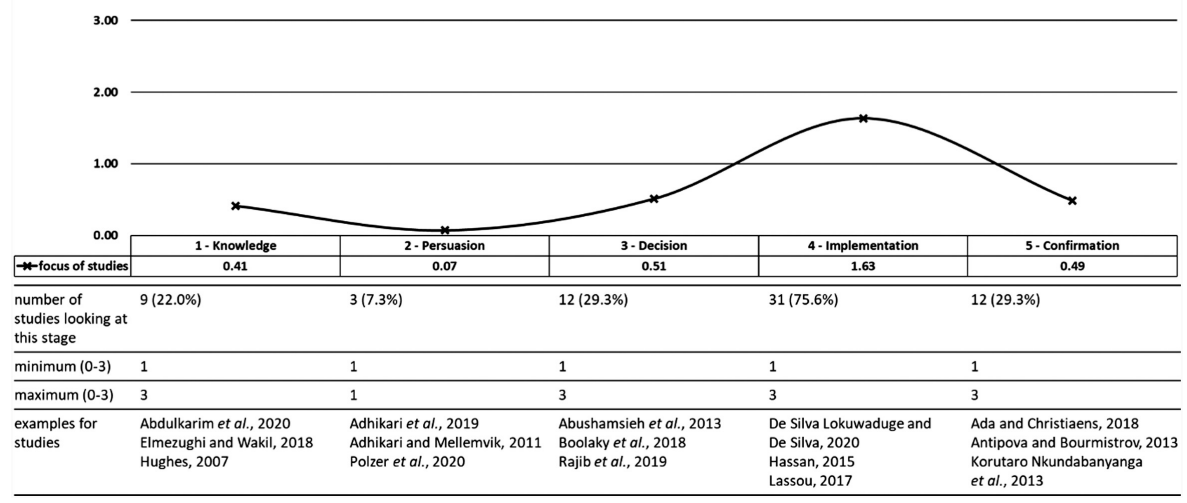


recommended that training programmes be developed to equip employees with up-to-date knowledge about IPSAS, because of the complex nature of the standards".

4.2.2 Persuasion. Second, persuasion is an issue for under $10 \%$ of studies (these are Adhikari et al., 2019; Adhikari and Mellemvik, 2011; Polzer et al., 2020). This low value might indicate that - in contrast to western countries - EEs and LICs have a limited say about the general decision to adopt IPSASs, as this reform often appears as a supplier-led reform encouraged by international organisations. This directs attention to the bottom part of our analytical framework (i.e. the contextual factors of adoption).

4.2.3 Decision. About $30 \%$ of pieces address the decision stage. Here, studies bring issues of non-participation of stakeholders in EEs and LICs to the forefront. For example, Rajib et al. (2019) find that the Cash Basis IPSAS in Bangladesh was adopted in a rather top-down manner without consulting professional accounting bodies (see Zaman Mir and Shiraz Rahaman (2005) for a similar account on the adoption of international accounting standards in the private sector). Drawing on the experiences from other Arab countries, Abushamsieh et al. (2013) develop a framework facilitating the adoption decision in Palestine based on contingency theory (Lüder, 1992). The study by Boolaky et al. (2018) is a chronology of decisions in Indonesia (PSA regulatory changes including IPSASs).

4.2.4 Implementation. The majority of papers (about three-quarters) focus on the implementation stage of IPSASs adoption. Here, studies often analyse the factors that facilitate or impede implementation (often in research that deploys a contingency theory framework). Hindering factors include political uncertainty (De Silva Lokuwaduge and De Silva, 2020), insufficient training of public sector accountants (Polzer et al., 2020; Rajib et al., 2019), further institutional incapability (Hassan, 2015) or patronage (Lassou, 2017). In their comparative study of Egypt, Nepal and Sri Lanka, Adhikari et al. (2019) state that delay and resistance have often become the key characteristics of PSA reforms, including IPSAS reforms at the implementation stage.

4.2.5 Confirmation. Another $30 \%$ of the studies describe the final stage in Rogers' (2003) model, which looks at reform outcomes (Figure 6). Research often discusses decoupling (e.g. Ada and Christiaens, 2018; Antipova and Bourmistrov, 2013; Hassan, 2015; Lassou, 2017). Also, Goddard et al. (2016, p. 19) find that "despite the inherent weaknesses facing the implementation of IPSAS, all financial statements of the Tanzanian Councils were stamped as "fully IPSAS compliant". The research by Adhikari and Jayasinghe (2017) provides evidence that the reform in Nepal has not been materialised, which is mainly due to the inability of reform propagators to make a considerable impact on the internal structures of government accountants. On a more positive note, the paper by Korutaro Nkundabanyanga et al. (2013, p. 65) on Uganda finds "that accounting standards and legal frameworks are all positively and significantly associated with the quality of financial reporting”. This suggests that enforcing compliance with standards can ultimately result in a successful adoption.

4.2.6 Contextual factors present in EEs and LICs. First, it is interesting to note that the majority of studies are silent on whether the IPSASs are regarded suitable to be adopted in EEs/LICs. While $78 \%$ of studies take a neutral stance, about $17 \%$ take a positive one and the rest are openly critical towards IPSASs adoption by EEs and LICs. For example, Legenkova's article (2016) concludes that the adoption of IPSASs could contribute to the Russian Federal Government's goal to deliver services more effectively and efficiently. In contrast, the research by Carolini (2010, p. 469) argues that IPSASs currently "fail to adequately encompass and address the voices and concerns of governments in the global South". Bakre et al. (2017) illustrate that IPSASs can even foster corruption in a patronage-based culture, and Jayasinghe et al. (2020) question the significance of IPSASs for EEs/LICs, which tend to de-emphasise the elements of existing good accounting practices.

In order to overcome decoupling, a number of papers point towards the necessity to respect national peculiarities in EEs and LICs when implementing the IPSASs (e.g. Adhikari 
et al., 2013). This is in line with what studies have found on the adoption of private sector IFRSs (e.g. Nguyen and Dinh Khoi Nguyen, 2012). Having this in mind, in order to accommodate the idiosyncrasies of EEs and LICs, a sequencing or prioritisation reform approach is suggested, i.e. carrying out basic reforms first before more advanced PSA reforms are undertaken (Bietenhader and Bergmann, 2010) - for example, introducing consolidated financial statements (Santis et al., 2018). Such an approach is also emphasised by the World Bank (2010) that recommends that EEs and LICs implement the Cash Basis IPSAS first before rolling out the full set of IPSASs (Adhikari and Mellemvik, 2010). More recently, Jayasinghe et al. (2020) argue that in many EEs/LICs some elements of good government accounting practices already exist, and reforms should build on these rather than initiating new large-scale reform projects.

\section{Discussion and avenues for further research}

When applying our analytical framework to assess the literature (Figure 6), our findings demonstrated that much of the empirical research centred on the implementation stage of the IPSASs. For each of the stages, the studies provided accounts on the idiosyncrasies of EEs and LICs (Hopper et al., 2017; Soobaroyen et al., 2017). An explanation for the low number of studies that focused on the persuasion stage could be that the adoption is externally driven or supply-led innovation. In terms of outcomes or success of IPSASs adoption initiatives, the (limited) evidence was mixed. While some studies present positive accounts (at least regarding some aspects), issues of decoupling between adopted standards and their actual use are frequently reported, indicating a lack of confirmation of the diffusion.

\subsection{Research agenda}

We propose the following areas for further research ("what do we need to know?"). First, research to fill the identified blank spots in the analytical framework (Figure 6) is proposed. Here, we call in particular for more analytical works assessing the outcomes (confirmation stage) of IPSASs in different contexts. The study by Bakre et al. (2017) on the adoption of IPSAS 17 in Nigeria is a good example. Given a weak regulatory framework and ineffective governmental institutions, "the promise of using alien accounting standards such as IPSAS 17 to purportedly improve transparency and accountability in property sales and the monetisation of fringe benefits to public officials was ultimately unfulfilled" (ibid., p. 1303). Indeed, formally introducing IPSASs might end up as an exercise that adds little to improving PSA and development without corresponding monitoring of progress (Bakre et al., 2021; Soobaroyen et al., 2017).

Second, the results revealed that the persuasion and decision stages are under-researched, and in particular the role of local stakeholders such as professional accounting bodies and professional associations of public sector accountants who will work with the new standards on a day-to-day basis. The research by Rajib et al. (2019) contrasts the involvement of stakeholders in decision-making in Sri Lanka and Nepal with their non-involvement in Bangladesh during this stage. The paper by Antipova and Bourmistrov (2013) on Russia suggests that the followed top-down approach did not involve what they refer to as "context ambassadors" very much - but the buy-in of these is needed for the reforms to succeed. With this, we require more in-depth insights as to how to secure the commitment of accountants and users of financial reporting in the course of deciding on the adoption.

Third, developing strong PSA systems in EEs and LICs has been argued to be important for a number of reasons. According to a study by ACCA (2010, p. 2), PSA systems impact "on a broad range of areas including: aggregate financial management - fiscal sustainability; resource mobilisation and allocation; operational management - performance, value-for-money and budget management; governance - transparency and accountability; fiduciary risk management 
- controls, compliance and oversight. In addition, effective public financial management is important for decision making". Looking at the co-occurrence network of keywords from the papers (Figure 5), we see that IPSASs adoption is linked to PSA and wider administrative reform issues such as transparency, accountability and regulation, but not overly to topics such as decision-making, budgeting, fiscal sustainability and fiduciary management. Exploring the relationship of IPSASs with these issues (and potentially also risk management), i.e. their "interlinking theorisation" (Höllerer et al., 2020, p. 1284), could be an area for further studies.

Related to this, the voiced downsides of IPSASs of (1) initially offering limited public sectorspecific provisions in recognising, for example, transactions relating to social benefits and tax revenues and (2) not covering budgeting issues, which is central for countries where public finance is centred around the annual budget, have made the usefulness of IPSASs largely redundant in contexts also beyond EEs and LICs (Adhikari and Garseth-Nesbakk, 2016; European Commission, 2012). This has triggered, for example, a momentum towards developing a separate set of European Public Sector Accounting Standards (EPSASs), especially focusing on the European context, as part of harmonising PSA (Manes Rossi et al., 2016).

Fourth, we call for more research on the regional and local level and the level of individual organisations. This is, for example, done in Chow and Aggestam Pontoppidan's (2019) study, which focuses on IPSAS adoption in the United Nations System of Organizations. It is on this level where the majority of public services are delivered to citizens and where IPSASs can potentially contribute instantaneously to increasing transparency and discharging accountability. Here, IPSASs adoption could be linked to the debate of the publicness of PSA, and the localisation of reforms in particular (Steccolini, 2019).

Fifth, through the application of diffusion theory, we have delineated a clear trajectory of ongoing PSA reforms in EEs/LICs. IPSAS reforms are at different stages in different EE/LIC contexts and these reforms are encountering varied challenges and obstacles as they traverse each successive stage. Prior work discusses that the diffusion of public sector innovation is not automatic (Adhikari et al., 2015, 2019; Dissanayake et al., 2020; Ezzamel et al., 2014). However, rarely has prior work delineated a holistic understanding of where and at what stages IPSAS reforms stand in EEs/LICs, and which factors influence the progression of reforms at the next stage. For instance, our findings show that almost $70 \%$ of IPSAS reforms have been unable to reach the confirmation stage and that confirmation has been manipulated in many cases (Bakre et al., 2017; Goddard et al., 2016). Given that many EEs/LICs are in the process of converging with IPSASs (Gómez-Villegas et al., 2020), further research is warranted focusing on issues relating to the confirmation stage of the diffusion of PSA reforms.

Finally, we reiterate a number of calls from the papers regarding studying the particular challenges that EEs and LICs are facing, such as the consequences of the global financial crisis about a decade ago (Amiri and Hamza, 2020; Ben Amor and Damak Ayadi, 2019; Timoshenko and Adhikari, 2010) and recently the COVID-19 pandemic. In the advent of the pandemic, reporting of balance sheet risks and guarantees and contingent liabilities have been key issues in PSA (Anderson and Burke, 2021). While the first empirical research has been published in the area of budgeting (see the Special Issue edited by Grossi et al. (2020) in this journal), we call for an extension of the scope to financial accounting and reporting. Further studies along the suggested lines may help to clear some of the "blank spots" (or reduce them) and eventually foster an understanding of IPSAS diffusion in EEs and LICs.

\subsection{Practical implications and conclusion}

In addition to the outlined research avenues, we derive a number of practical implications from this research.

First, this research echoes observations made by previous authors (Bakre et al., 2021; Hopper et al., 2017; Jayasinghe et al., 2020), who make a call to take the characteristics of EEs 
and LICs into account when adopting (public sector) accounting reforms. The main point here is not to "wash away" the structures already in place, but to make "an 'intelligent' application of existing regulations and accounting systems" (Jayasinghe et al., 2020, p. 1) when adopting a "development accounting" instrument (Jayasinghe and Wickramasinghe, 2011, p. 410) such as IPSASs.

Second, IPSAS reforms are interconnected to a wider range of (PSA and public sector) reform activities, for example enhancing systems of accountability (Figure 5) or internal auditing capacities (Nerantzidis et al., 2020). After an assessment of institutional capability (Hassan, 2015), a sequencing/prioritisation approach (Bietenhader and Bergmann, 2010) might be suggested, i.e. starting reforms with more basic issues or reform packages before implementing more advanced instruments. Also, IPSASs could be first introduced in pilot entities (Jorge et al., 2020).

Finally, in line with Chan (2006) and Rajib et al. (2019), we argue that the implementation of IPSASs in EEs and LICs often requires a large investment in educating and training public sector employees to develop a new range of accounting skills.

To conclude, this is the first review of IPSASs in EEs and LICs to structure the extant literature and point to under-researched areas. However, as with all empirical research, there are a number of limitations to this study. First, our methodological setup did not enable us to include materials such as books, edited volumes, journals that are not peer-reviewed and material in languages other than English in our review. Further research could address this shortcoming (Massaro et al., 2016). Also, IPSASs need to be contextualised in the broader "ecosystem" of administrative reforms in the public sectors of EEs and LICs. Further research could, for example, explore how IPSASs relate to broader managerial reforms in these countries (Hepworth, 2015) and how they relate to "good governance" principles, such as transparency and accountability (e.g. Bakre et al., 2021).

\section{Note}

1. In this review, we follow the criteria of the Journal of Accounting in Emerging Economies to determine which countries are considered as EEs (Tsamenyi and Uddin, 2011). EEs are countries within lower- to upper-middle-income bands according to the World Bank, as well as ex-communist countries in Europe, upper-income countries from the Middle East and ASEAN countries (as these countries bear socio-economic similarities to the countries as per the World Bank list). LICs are lowincome countries as per the World Bank classification: https://datahelpdesk.worldbank.org/ knowledgebase/articles/906519-world-bank-country-and-lending-groups - retrieved: 01/12/2020.

\section{References}

Abdulkarim, M.E., Umlai, M.I. and Al-Saudi, L.F. (2020), "Exploring the role of innovation in the level of readiness to adopt IPSAS”, Journal of Accounting and Organizational Change, Vol. 16 No. 3, pp. 469-495.

Abushamsieh, K., López Hernández, A.M. and Ortiz Rodríguez, D. (2013), "The transparency of government financial information systems in Arab countries: evidence from Palestine", Journal of Accounting - Business and Management, Vol. 20 No. 2, pp. 99-112.

ACCA (2010), Improving Public Sector Financial Management in Developing Countries and Emerging Economies, Association of Chartered Certified Accountants, London.

ACCA (2017), IPSAS Implementation: Current Status and Challenges, Association of Chartered Certified Accountants, London.

Ada, S.S. and Christiaens, J. (2018), "The magic shoes of IPSAS: will they fit Turkey?”, Transylvanian Review of Administrative Sciences, Vol. 54 No. 1, pp. 5-21.

Adam, B. (2018), "Comparison of the perception of overt and covert options in IPSAS financial statements by intergovernmental organizations", Tékhne, Vol. 16 No. 1, pp. 28-39. 
Adhikari, P. and Gårseth-Nesbakk, L. (2016), "Implementing public sector accruals in OECD member states: major issues and challenges", Accounting Forum, Vol. 40 No. 2, pp. 125-142.

Adhikari, P. and Jayasinghe, K. (2017), “'Agents-in-focus' and 'Agents-in-context': the strong structuration analysis of central government accounting practices and reforms in Nepal", Accounting Forum, Vol. 41 No. 2, pp. 96-115.

Adhikari, P. and Mellemvik, F. (2010), "The adoption of IPSASs in South Asia: a comparative study of seven countries", Research in Accounting in Emerging Economies, Vol. 10 No. 1, pp. 169-199.

Adhikari, P. and Mellemvik, F. (2011), "The rise and fall of accruals: a case of Nepalese central government", Journal of Accounting in Emerging Economies, Vol. 1 No. 2, pp. 123-143.

Adhikari, P., Kuruppu, C. and Matilal, S. (2013), "Dissemination and institutionalization of public sector accounting reforms in less developed countries: a comparative study of the Nepalese and Sri Lankan central governments", Accounting Forum, Vol. 37 No. 3, pp. 213-230.

Adhikari, P., Kuruppu, C., Wynne, A. and Ambalangodage, D. (2015), "Diffusion of the cash basis international public sector accounting standard (IPSAS) in less developed countries (LDCs) the case of the Nepali central government", Research in Accounting in Emerging Economies, Vol. 15 No. 1, pp. 85-108.

Adhikari, P., Kuruppu, C., Ouda, H., Grossi, G. and Ambalangodage, D. (2019), "Unintended consequences in implementing public sector accounting reforms in emerging economies: evidence from Egypt, Nepal and Sri Lanka”, International Review of Administrative Sciences. doi: $10.1177 / 0020852319864156$.

Alsharari, N.M. (2020), "Accounting changes and beyond budgeting principles (BBP) in the public sector”, International Journal of Public Sector Management, Vol. 33 Nos 2/3, pp. 165-189.

Amiri, A. and Hamza, S.E. (2020), "The transition to IPSAS standards: the extent of adoption and the influence of institutional, contingency and economic network factors", Journal of Accounting and Management Information Systems, Vol. 19 No. 2, pp. 215-251.

Anderson, B. and Burke, K. (2021), Budgeting for Loans and Guarantees: The United States Federal Credit Reform Act, OECD Working Party of Senior Budget Officials, Paris.

Antipova, T. and Bourmistrov, A. (2013), "Is Russian public sector accounting in the process of modernization? An analysis of accounting reforms in Russia", Financial Accountability and Management, Vol. 29 No. 4, pp. 442-478.

Araya-Leandro, C., Caba-Pérez, M.D.C. and López-Hernandez, A.M. (2016), "The convergence of the Central American countries to international accounting standards", Revista de Administração Pública, Vol. 50 No. 2, pp. 265-283.

Bakre, O., Lauwo, S.G. and McCartney, S. (2017), "Western accounting reforms and accountability in wealth redistribution in patronage-based Nigerian society", Accounting, Auditing and Accountability Journal, Vol. 30 No. 6, pp. 1288-1308.

Bakre, O.M., McCartney, S. and Fayemi, S.O. (2021), "Accounting as a technology of neoliberalism: the accountability role of IPSAS in Nigeria”, Critical Perspectives on Accounting. doi: 10.1016/j.cpa. 2020.102282.

Baskerville, R. and Grossi, G. (2019), "Glocalization of accounting standards: observations on neoinstitutionalism of IPSAS”, Public Money and Management, Vol. 39 No. 2, pp. 95-103.

Bénit-Gbaffou, C. (2018), "Beyond the policy-implementation gap: how the City of Johannesburg manufactured the ungovernability of street trading", The Journal of Development Studies, Vol. 54 No. 12, pp. 2149-2167.

Ben Amor, D. and Damak Ayadi, S. (2019), "The profile of IPSAS-adopters", Journal of Accounting and Management Information Systems, Vol. 18 No. 2, pp. 262-282.

Bietenhader, D. and Bergmann, A. (2010), "Principles for sequencing public financial reforms in developing countries", International Public Management Review, Vol. 11 No. 1, pp. 52-66. 
Boolaky, P.K., Mirosea, N. and Singh, K. (2018), "On the regulatory changes in government accounting development in Indonesia. A chronology from colonisation and post-colonisation era”, Journal of Accounting in Emerging Economies, Vol. 8 No. 3, pp. 387-411.

Bracci, E., Papi, L., Bigoni, M., Deidda Gagliardo, E. and Bruns, H.-J. (2019), "Public value and public sector accounting research: a structured literature review", Journal of Public Budgeting, Accounting and Financial Management, Vol. 31 No. 1, pp. 103-136.

Brusca, I., Montesinos, V. and Chow, D.S.L. (2013), "Legitimating International Public Sector Accounting Standards (IPSAS): the case of Spain”, Public Money and Management, Vol. 33 No. 6, pp. 437-444.

Carolini, G.Y. (2010), "The tools of whose trade? How international accounting guidelines are failing governments in the global South", Third World Quarterly, Vol. 31 No. 3, pp. 469-483.

Cavanagh, J. and Fernández Benito, A. (2016), "Public accounting and fiscal credibility", in Pimenta, C. and Pessoa, M. (Eds), Public Financial Management in Latin America. The Key to Efficiency and Transparency, International Monetary Fund, Washington, DC, pp. 183-236.

Cenar, I. (2012), "Call for professional judgment policy and accounting estimates changes wihin public institutions", Annales Universitatis Apulensis Series Oeconomica, Vol. 14 No. 2, pp. 348-356.

Chan, J. (2003), "Government accounting: an assessment of theory, purposes and standards", Public Money and Management, Vol. 23 No. 1, pp. 13-20.

Chan, J.L. (2006), "IPSAS and government accounting reform in developing countries", in Lande, E. and Scheid, J.-C. (Eds), Accounting Reform in the Public Sector: Mimicry, Fad or Necessity, Expert Comptable Media, Paris, pp. 31-42.

Chow, D.S.L. and Aggestam Pontoppidan, C. (2019), “The United Nations' (UN) decision to adopt International Public Sector Accounting Standards (IPSAS)", Journal of Public Budgeting, Accounting and Financial Management, Vol. 31 No. 2, pp. 285-306.

Christiaens, J., Vanhee, C., Manes-Rossi, F., Aversano, N. and Van Cauwenberge, P. (2015), "The Effect of IPSAS on reforming governmental financial reporting: an international comparison", International Review of Administrative Sciences, Vol. 81 No. 1, pp. 158-177.

De Silva Lokuwaduge, C.S. and De Silva, K. (2020), "Determinants of public sector accounting reforms", International Journal of Public Sector Management, Vol. 33 Nos 2/3, pp. 191-205.

de Vries, H., Bekkers, V. and Tummers, L. (2016), "Innovation in the public sector: a systematic review and future research agenda", Public Administration, Vol. 94 No. 1, pp. 146-166.

De Waele, L., Polzer, T., van Witteloostuijn, A. and Berghman, L. (2021), “A little bit of everything?' Conceptualising performance measurement in hybrid public sector organisations through a literature review", Journal of Public Budgeting, Accounting and Financial Management, Vol. 33 No. 3, pp. 343-363.

Deaconu, A., Nistor, C.S. and Filip, C. (2011), "The impact of accrual accounting on public sector management. An exploratory study for Romania", Transylvanian Review of Administrative Sciences, No. 32E, pp. 74-97.

Dissanayake, T., Dellaportas, S. and Yapa, P.W.S. (2020), "The diffusion-adoption of accrual accounting in Sri Lankan local governments", Financial Accountability and Management, Vol. 36 No. 3, pp. 261-277.

Elmezughi, A. and Wakil, A.A. (2018), "Feasibility of transformation to accrual basis of accounting in the public sector: Kingdom of Bahrain Context", Academy of Accounting and Financial Studies Journal, Vol. 22 No. 6, pp. 1-15.

European Commission (2012), Public Consultation - Assessment of the Suitability of the International Public Sector Accounting Standards for the Member States. Summary of Responses, European Commission, Brussels.

Ezzamel, M., Hyndman, N., Johnsen, A. and Lapsley, I. (2014), "Reforming central government: an evaluation of an accounting innovation”, Critical Perspectives on Accounting, Vol. 25 Nos 4-5, pp. $409-422$. 
Fahmid, I.M., Harun, H., Graham, P., Carter, D., Suhab, S., An, Y., Zheng, X. and Fahmid, M.M. (2020), "New development: IPSAS adoption, from G20 countries to village governments in developing countries", Public Money and Management, Vol. 40 No. 2, pp. 160-163.

Goddard, A., Assad, M., Issa, S., Malagila, J. and Mkasiwa, T.A. (2016), "The two publics and institutional theory - a study of public sector accounting in Tanzania", Critical Perspectives on Accounting, Vol. 40 No. 1, pp. 8-25.

Gómez-Villegas, M., Brusca, I. and Bergmann, A. (2020), "IPSAS in Latin America: innovation, isomorphism or rhetoric?", Public Money and Management, Vol. 40 No. 7, pp. 489-498.

Greenwood, R., Oliver, C., Lawrence, T.B. and Meyer, R.E. (2017), "Introduction: into the fourth decade", in Greenwood, R., Oliver, C., Lawrence, T.B. and Meyer, R.E. (Eds), The SAGE Handbook of Organizational Institutionalism, Sage, Los Angeles, pp. 1-23.

Grossi, G., Ho, A.T. and Joyce, P.G. (2020), "Budgetary responses to a global pandemic: international experiences and lessons for a sustainable future", Journal of Public Budgeting, Accounting and Financial Management, Vol. 32 No. 5, pp. 737-744.

Grubišić, M., Nušinović, M. and Roje, G. (2009), "Towards efficient public sector asset management", Financial Theory and Practice, Vol. 33 No. 3, pp. 329-362.

Harun, H., Mir, M., Carter, D. and An, Y. (2019), "Examining the unintended outcomes of NPM reforms in Indonesia", Public Money and Management, Vol. 39 No. 2, pp. 86-94.

Hassan, M.M. (2015), "Transformation to more accrual-based accounting practices in Indonesian government", Journal of International Business Research, Vol. 14 No. 1, pp. 139-165.

Hepworth, N. (2015), "Debate: implementing advanced public financial management reform in developing countries", Public Money and Management, Vol. 35 No. 4, pp. 251-253.

Hepworth, N. (2017), "Is implementing the IPSASs an appropriate reform?", Public Money and Management, Vol. 37 No. 2, pp. 141-148.

Höllerer, M.A., Jancsary, D., Barberio, V. and Meyer, R.E. (2020), "The interlinking theorization of management concepts: cohesion and semantic equivalence in management knowledge", Organization Studies, Vol. 41 No. 9, pp. 1284-1310.

Hopper, T., Lassou, P. and Soobaroyen, T. (2017), "Globalisation, accounting and developing countries", Critical Perspectives on Accounting, Vol. 43, pp. 125-148.

Hughes, J.W. (2007), "Transitioning from current basis to full accrual basis of accounting for governments in developing countries", The Journal of Government Financial Management, Vol. 56 No. 3, pp. 20-26.

IFAC (2011), Transition to the Accrual Basis of Accounting: Guidance for Public Sector Entities, IFAC, New York.

IPSASB (2010), Update of Study 14 - Transition to the Accrual Basis of Accounting: Guidance for Governments and Government Entities, IFAC, New York.

Jackson, A. and Lapsley, I. (2003), "The diffusion of accounting practices in the new "managerial" public sector", International Journal of Public Sector Management, Vol. 16 No. 5 , pp. 359-372.

Jayasinghe, K. and Wickramasinghe, D. (2011), "Power over empowerment: encountering development accounting in a Sri Lankan fishing village", Critical Perspectives on Accounting, Vol. 22 No. 4, pp. 396-414.

Jayasinghe, K., Adhikari, P., Wynne, A., Malagila, J., Abdurafiu, N. and Soobaroyen, T. (2020), "Government accounting reforms in Sub-Saharan African Countries and the selective ignorance of the epistemic community: a competing logics perspective", Critical Perspectives on Accounting. doi: 10.1016/j.cpa.2020.102246.

Jensen, G. (2020), “The IPSASB's recent strategies: opportunities for academics and standardsetters", Journal of Public Budgeting, Accounting and Financial Management, Vol. 32 No. 3, pp. 315-319. 
Jorge, S., Nogueira, S.P. and Ribeiro, N. (2020), "The institutionalization of public sector accounting reforms: the role of pilot entities", Journal of Public Budgeting, Accounting and Financial Management, Vol. 33 No. 2, pp. 114-137.

Kartiko, S.W., Rossieta, H., Martani, D. and Wahyuni, T. (2018), "Measuring accrual-based IPSAS implementation and its relationship to central government fiscal transparency", BAR Brazilian Administration Review, Vol. 15 No. 4.

Korutaro Nkundabanyanga, S., Tauringana, V., Balunywa, W. and Naigo Emitu, S. (2013), "The association between accounting standards, legal framework and the quality of financial reporting by a government ministry in Uganda”, Journal of Accounting in Emerging Economies, Vol. 3 No. 1, pp. 65-81.

Kumar, S., Pandey, N. and Haldar, A. (2020), "Twenty years of public management review (PMR): a bibliometric overview", Public Management Review, Vol. 22 No. 12, pp. 1876-1896.

Lapsley, I. and Wright, E. (2004), "The diffusion of management accounting innovations in the public sector: a research agenda", Management Accounting Research, Vol. 15 No. 3, pp. 355-374.

Lassou, P.J.C. (2017), "State of government accounting in Ghana and Benin: a 'tentative' account", Journal of Accounting in Emerging Economies, Vol. 7 No. 4, pp. 486-506.

Legenkova, M. (2016), "International Public Sector Accounting Standards implementation in the Russian Federation”, International Journal of Economics and Financial Issues, Vol. 6 No. 4, pp. 1304-1309.

Liguori, M. and Steccolini, I. (2012), "Accounting change: explaining the outcomes, interpreting the process", Accounting, Auditing and Accountability Journal, Vol. 25 No. 1, pp. 27-70.

Lüder, K. (1992), "A contingency model for governmental accounting innovations in the politicaladministrative environment", Research in Governmental and Nonprofit Accounting, Vol. 7, pp. 99-127.

Manes Rossi, F., Cohen, S., Caperchione, E. and Brusca, I. (2016), "Harmonizing public sector accounting in Europe: thinking out of the box", Public Money and Management, Vol. 36 No. 3, pp. 189-196.

Manes-Rossi, F., Nicolò, G. and Argento, D. (2020), "Non-financial reporting formats in public sector organizations: a structured literature review", Journal of Public Budgeting, Accounting and Financial Management, Vol. 32 No. 4, pp. 639-669.

Massaro, M., Dumay, J. and Guthrie, J. (2016), "On the shoulders of giants: undertaking a structured literature review in accounting", Accounting, Auditing and Accountability Journal, Vol. 29 No. 5 , pp. $767-801$.

Mattei, G., Jorge, S. and Grandis, F.G. (2020), "Comparability in IPSASs: lessons to be learned for the European standards", Accounting in Europe, Vol. 17 No. 2, pp. 158-182.

Mir, M. and Sutiyono, W. (2013), "Public sector financial management reform: a case study of local government agencies in Indonesia", Australasian Accounting Business and Finance Journal, Vol. 7 No. 4, pp. 98-117.

Moher, D., Liberati, A., Tetzlaff, J. and Altman, D.G. (2009), "Reprint - preferred reporting items for systematic reviews and meta-analyses: the PRISMA statement", Physical Therapy, Vol. 89 No. 9, pp. $873-880$.

Mouritsen, J. (2005), "Beyond accounting change: design and mobilisation of management control systems", Journal of Contemporary Accounting \& Organizational Change, Vol. 1 No. 1, pp. 97-133.

Mustapha, M., Ismail, K.N.I.K. and Ahmad, H.N. (2019), "Professionalism, competency and financial reporting quality: a perception of Director of Finance in a changing public sector reporting standard", Jurnal Pengurusan, Vol. 57 No. 1, pp. 1-19.

Nerantzidis, M., Pazarskis, M., Drogalas, G. and Galanis, S. (2020), "Internal auditing in the public sector: a systematic literature review and future research agenda", Journal of Public Budgeting, Accounting and Financial Management. doi: 10.1108/JPBAFM-02-2020-0015. 
Nguyen, P.C. and Dinh Khoi Nguyen, T. (2012), "International harmonization and national particularities of accounting", Journal of Accounting and Organizational Change, Vol. 8 No. 3, pp. 431-451.

Nolte, I.M., Polzer, T. and Seiwald, J. (2021), "Gender budgeting in emerging economies - a systematic literature review and research agenda”, Journal of Accounting in Emerging Economies. doi: 10. 1108/JAEE-03-2020-0047.

North, D.C., Wallis, J.J., Webb, S.B. and Weingast, B.R. (2013), "Lessons - in the shadow of violence", in North, D.C., Wallis, J.J., Webb, S.B. and Weingast, B.R. (Eds), In the Shadow of Violence: Politics, Economics and the Problems of Development, Cambridge University Press, Cambridge, pp. 328-350.

Nurunnabi, M. (2020), "Editorial: International Public Sector Accounting Standards (IPSAS): current status, practices and future agenda", International Journal of Public Sector Management, Vol. 33 Nos 2/3, pp. 113-115.

Oulasvirta, L. (2014), "The reluctance of a developed country to choose International Public Sector Accounting Standards of the IFAC. A critical case study", Critical Perspectives on Accounting, Vol. 25 No. 3, pp. 272-285.

Podsakoff, P.M., MacKenzie, S.B., Bachrach, D.G. and Podsakoff, N.P. (2005), "The influence of management journals in the 1980s and 1990s", Strategic Management Journal, Vol. 26 No. 5, pp. 473-488.

Polzer, T., Gårseth-Nesbakk, L. and Adhikari, P. (2020), “Does your walk match your talk?' Analyzing IPSASs diffusion in developing and developed countries", International Journal of Public Sector Management, Vol. 33 Nos 2/3, pp. 117-139.

Polzer, T., Grossi, G. and Reichard, C. (2021a), "The harmonization of public sector accounting and diffusion of IPSAS”, in Brusca, I., Gomes, P., Fernandes, M.J. and Montesinos, V. (Eds), Challenges in the Adoption of International Public Sector Accounting Standards. The Experience of the Iberian Peninsula as a Front Runner, Palgrave Macmillan, Cham, pp. 17-34.

Polzer, T., Grossi, G. and Reichard, C. (2021b), "Implementation of the International Public Sector Accounting Standards in Europe. Variations on a global Theme", Accounting Forum. doi: 10. 1080/01559982.2021.1920277.

Polzer, T., Nolte, I.M. and Seiwald, J. (2021c), "Gender budgeting in public financial management: a literature review and research agenda", International Review of Administrative Sciences. doi: 10. 1177/00208523211031796.

Polzer, T., Reichard, C. and Grossi, G. (2021d), "Organization of the IPSASB, conceptual framework and claimed benefits and criticisms of IPSAS", in Brusca, I., Gomes, P., Fernandes, M.J. and Montesinos, V. (Eds), Challenges in the Adoption of International Public Sector Accounting Standards. The Experience of the Iberian Peninsula as a Front Runner, Palgrave Macmillan, Cham, pp. 1-16.

$\mathrm{PwC}$ (2013), Towards a New Era in Government Accounting and Reporting, PwC, Brussels.

Rajib, S.U., Adhikari, P., Hoque, M. and Akter, M. (2019), "Institutionalisation of the cash basis international public sector accounting standard in the central government of Bangladesh", Journal of Accounting in Emerging Economies, Vol. 9 No. 1, pp. 28-50.

Ratmono, D. and Sutrisno (2019), "Financial statements quality of central government entities: a test of institutional and agency theories", Academy of Accounting and Financial Studies Journal, Vol. 23 No. 3, pp. 1-15.

Rogers, E.M. (2003), Diffusion of Innovations, Free Press, New York.

Saleh, Z. and Pendlebury, M.W. (2006), "Accruals accounting in government - developments in Malaysia”, Asia Pacific Business Review, Vol. 12 No. 4, pp. 421-435.

Santis, S., Grossi, G. and Bisogno, M. (2018), "Public sector consolidated financial statements: a structured literature review", Journal of Public Budgeting, Accounting and Financial Management, Vol. 30 No. 2, pp. 230-251. 
Schmidthuber, L., Hilgers, D. and Hofmann, S. (2020), "International Public Sector Accounting Standards (IPSASs): a systematic literature review and future research agenda", Financial Accountability and Management. doi: 10.1111/faam.12265.

Scimago Research Group (2007), Description of SCImago Journal Rank Indicator, available at: http:// www.scimagojr.com/SCImagoJournalRank.pdf (accessed 0109 2020).

Soobaroyen, T., Tsamenyi, M. and Sapra, H. (2017), "Accounting and governance in Africa contributions and opportunities for further research", Journal of Accounting in Emerging Economies, Vol. 7 No. 4, pp. 422-427.

Sour, L. (2020), "New development: integration of budget and governmental accounting in Mexican states", Public Money and Management, Vol. 40 No. 7, pp. 519-522.

Steccolini, I. (2019), “Accounting and the post-new public management: re-considering publicness in accounting research", Accounting, Auditing and Accountability Journal, Vol. 32 No. 1, pp. 255-279.

Thoradeniya, P., Ferreira, A., Lee, J. and Tan, R. (2020), "The diffusion of sustainability key performance indicators in a developing country context", Accounting, Auditing and Accountability Journal. doi: 10.1108/AAAJ-07-2019-4106.

Timoshenko, K. and Adhikari, P. (2010), "A two-country comparison of public sector accounmting reforms: same ideas, different paths?", Journal of Public Budgeting, Accounting and Financial Management, Vol. 22 No. 4, pp. 449-486.

Tiron Tudor, A. (2010), "Romanian public institutions financial statements on the way of harmonization with IPSAS”, Accounting and Management Information Systems, Vol. 9 No. 3, pp. $422-447$.

Tooley, S., Hooks, J. and Basnan, N. (2010), "Performance reporting by Malaysian local authorities: identifying stakeholder needs", Financial Accountability and Management, Vol. 26 No. 2, pp. 103-133.

Torres, L. (2004), "Accounting and accountability: recent developments in government financial information systems”, Public Administration and Development, Vol. 24 No. 5, pp. 447-456.

Tsamenyi, M. and Uddin, S. (2011), "Editorial”, Journal of Accounting in Emerging Economies, Vol. 1 No. 1, p. 1.

van Helden, J. and Uddin, S. (2016), "Public sector management accounting in emerging economies: a literature review", Critical Perspectives on Accounting, Vol. 41 No. 1, pp. 34-62.

Van Helden, J., Adhikari, P. and Kuruppu, C. (2021), "Public sector accounting in emerging economies: a review of the papers published in the first decade of Journal of Accounting in Emerging Economies", Journal of Accounting in Emerging Economies. doi: 10.1108/JAEE-02-2020-0038.

van Thiel, S. (2014), Research Methods in Public Administration and Public Management: An Introduction, Routledge, London and New York.

World Bank (2010), Public Sector Accounting and Auditing in South Asia, World Bank, Washington, DC.

Zaman Mir, M. and Shiraz Rahaman, A. (2005), "The adoption of international accounting standards in Bangladesh”, Accounting, Auditing and Accountability Journal, Vol. 18 No. 6, pp. 816-841.

\section{Corresponding author}

Tobias Polzer can be contacted at: tobias.polzer@wu.ac.at

For instructions on how to order reprints of this article, please visit our website:

www.emeraldgrouppublishing.com/licensing/reprints.htm

Or contact us for further details: permissions@emeraldinsight.com 